\title{
DILEMA PEMBANGUNAN BERWAWASAN GENDER: ANTARA PEMBERDAYAAN DAN EKSPLOITASI PEREMPUAN
}

\author{
Munafaroh \\ Institut Ilmi Keislaman Annuqayah (INSTIKA) Guluk-guluk Sumenep-Jawa Timur \\ E-mail: munafaroh.mt@gmail.com
}

\begin{abstract}
Abstrak: Kemiskinan dan perempuan merupakan dua isu penting yang tidak dapat dipisahkan satu sama lain. Hal ini dikarenakan perempuan merupakan kelompok yang paling rentan mengalami kekerasan dan penindasan akibat kemiskinan. Dalam rangka peningkatan ekonomi perempuan, pemerintah mencanangkan program PEP (Pemberdayaan Ekonomi Perempuan) yang diinstruksikan berdasarkan Inpres Nomor 9 Tahun 2000 tentang Pengarusutamaan Gender dalam Pembangunan Nasional. Pembangunan yang dimaksudkan di sini adalah pembangunan ekonomi yang berwawasan gender. Namun fakta di lapangan menunjukkan bahwa pembangunan ekonomi yang berwawasan gender tersebut tidak berjalan sebagaimana mestinya, salah satu penyebabnya adalah adanya bias gender dalam pandangan masyarakat terutama terkait dengan arti gender itu sendiri. Sehingga hal ini melahirkan pembidangan tugas-tugas berdasarkan jenis kelamin, yang kemudian membuat perempuan memiliki beban ganda (double burden). Beban ganda yang dipikul dan ditanggung perempuan ini kemudian membuat perempuan menjadi korban dari eksploitasi ekonomi. Perempuan-perempuan yang sebenarnya sudah diekspolitasi, terkadang justru tidak menyadari bahwa sebenarnya mereka telah dieksploitasi, hal ini dikarenakan bentuk-bentuk dari eksploitasi itu sendiri sudah dibentuk sedemikian rupa oleh para kaum pemodal sehingga tidak tampak sebagai eksploitasi terhadap perempuan. Pemberian beban ganda maupun eksploitasi ekonomi tersebut jelas bertentangan dengan apa yang telah diatur dalam hukum Islam maupun hukum positif. Karena dalam dua instrumen hukum tersebut, eksploitasi ekonomi terhadap perempuan tidak dapat dibenarkan.
\end{abstract}

Kata Kunci: gender, kemiskinan, perempuan, eksploitasi, islam, undang-undang

\section{PENDAHULUAN}

Kemiskinan saat ini menjadi sorotan utama hampir di seluruh dunia, karena akibat dari kemiskinan dapat menimbulkan berbagai macam ketimpangan sosial masyarakat, seperti bertambahnya tindakan kriminal, menimbulkan kelaparan, gizi buruk dan dapat merusak naluri ibu yang tega mencekik atau meracuni anaknya yang berisik minta makan. Dalam upaya untuk mengurangi kemiskinan yang terjadi saat ini pemerintah membuat program PEP (Pemberdayaan Ekonomi Perempuan). Program PEP kemudian oleh pemerintah diinstruksikan berdasarkan Inpres Nomor 9 Tahun 2000 tentang Pengarusutamaan Gender dalam Pembangunan Nasional. Pemberdayaan kaum perempuan adalah salah satu upaya untuk memajukan kesejahteraan bangsa karena kaum perempuan dengan jumlah yang sangat besar merupakan modal sosial yang potensial bagi kelangsungan pembangunan bangsa (pdiperjuangan.or.id, Surya Chandra Surapaty, 05/Oktober/2011).

Perempuan dipilih sebagai target dari PEP karena dari aspek ekonomi, kaum perempuan Indonesia masih banyak yang berada di bawah garis kemiskinan. Rendahnya pendapatan dan kurangnya akses dalam perekonomian membuat 


\section{9-138 | HARKAT: Media Komunikasi Islam Tentang Gender dan Anak, 11 (2), 2015}

kaum perempuan Indonesia semakin terpuruk. Saat ini 4,7 juta perempuan di Indonesia masih menganggur. Masih kuatnya budaya patriarki juga menyebabkan ketimpangan sosial sehingga kaum perempuan sulit mengakses pekerjaan, pendidikan dan aktualisasi diri (pdiperjuangan.or.id, Surya Chandra Surapati, 05/Oktober/2011). Hal ini menunjukkan bahwa kesejahteraan kaum perempuan di Indonesia masih berada jauh di bawah kaum laki-laki.

Perempuan adalah bagian dari masyarakat yang berhubungan sangat erat dengan masalah kesejahteraan masyarakat. Dalam keadaan krisis ekonomi, perempuanlah yang paling merasakan akibat dari krisis tersebut. Akan tetapi, dalam keadaan yang kritis, seringkali perempuan lebih mempunyai inisiatif, bangkit dan menggerakkan masyarakat sekitarnya untuk memperbaiki kondisi perekonomian, mulai dari perekonomian keluarga, meluas sampai ke perekonomian rakyat (SETNEG.GO.ID, Meutia Hatta Swasono, 28/September/2011). Hal ini menunjukkan bahwa perempuan juga mempunyai peran yang sangat besar bagi pembangunan suatu bangsa atau negara.

Peranan wanita dalam pembangunan yang dimaksud di atas adalah peranan wanita dalam pembangunan yang berwawasan gender, berarti peranan wanita dalam pembangunan sesuai dengan konsep gender atau peran gender yang mencakup peran produktif, peran reproduktif dan peran sosial yang sifatnya dinamis. Mengupayakan peranan wanita dalam pembangunan yang berwawasan atau berspektif gender, dimaksudkan untuk mewujudkan kesetaraan dan keadilan gender atau kemitrasejajaran yang harmonis antara pria dengan wanita di dalam pembangunan (DPD PKPB Banten, 28/Sepetember/2011).

Konsep pembangunan yang berwawasan gender sesungguhnya tidaklah menjadi masalah sepanjang tidak melahirkan ketidakadilan gender (gender ineqqualities). Namun yang menjadi persoalan, ternyata perbedaan gender telah melahirkan berbagai ketidakadilan, baik bagi kaum laki-laki dan terutama terhadap kaum perempuan (Mansour Fakih, 1996:12). Salah satu penyebab ketidakadilan ini adalah pola pikir masyarakat tentang arti gender itu sendiri, sehingga hal ini sangat berpengaruh bagi penerapan pembangunan yang berwawasan gender.

Dalam Women's Studies Encyclopedia, dijelaskan bahwa gender adalah seperangkat sikap, peran, fungsi dan tanggung jawab yang melekat pada diri laki-laki dan perempuan akibat bentukan budaya atau pengaruh lingkungan masyarakat di mana manusia itu tumbuh dan dibesarkan (Siti Musdah Mulia, 2011: 65). Hal ini dapat disimpulkan bahwa sebenarnya gender itu bukanlah sesuatu yang secara kodrati dimiliki oleh setiap manusia, melainkan sesuatu yang sengaja dibentuk oleh lingkungan di mana manusia itu hidup. Artinya, gender yang melekat tersebut dapat diubah sesuai dengan perkembangan masyarakat yang bersangkutan.

Pola pikir masyarakat yang sedari awal beranggapan bahwa gender adalah sesuatu yang permanen dan tidak dapat diubah (khusunya terkait pembagian tugas anatara laki-laki dan perempuan) kemudian melahirkan berbagai macam ketimpangan sosial. Di antaranya berupa burden atau pemberian beban kerja yang lebih panjang dan lebih berat kepada perempuan, terutama perempuan pekerja. Sebab, selain dituntut mampu menyelesaikan tugas-tugas rumah tangga, yang di masyarakat selalu dipersepsikan sebagai kewajiban perempuan, mereka juga harus menunjukkan prestasi kerja yang baik di tempat kerja (Siti Musdah Mulia, 2011: 66).

Di dalam hal kaitannya dengan pembangunan, pandangan bias gender tersebut oleh pemerintah dilembagakan dalam program pembangunan. Di sana disebutkan lima tugas utama perempuan (Panca Tugas Perempuan), 
yakni: (1) sebagai pendamping suami, (2) sebagai pendidik generasi muda, (3) sebagai pengatur rumah tangga, (4) sebagai tenaga kerja, (5) sebagai anggota organisasi masyarakat (Siti Musdah Mulia, 2011: 242).

Tugas utama perempuan yang dilembagakan dalam program pembangunan oleh pemerintah tersebut sebenarnya akan melahirkan permasalahan lain bagi perempuan, yaitu eksploitasi ekonomi. Eksploitasi merupakan suatu tindakan untuk memanfaatkan sesuatu secara berlebihan atau sewenang-wenang (www.pengertianmenurutparaahli.com, 16/ Februari/ 2016). Sedangkan arti ekonomi menurut Kamus Besar Bahasa Indonesia (KBBI) adalah pemanfaatan uang, tenaga, waktu dan sebagainya yang berharga. Berdasarkan kedua pengertian tersebut dapat disimpulkan bahwa yang dimaksud eksploitasi ekonomi perempuan adalah pemanfaatan perempuan sebagai penghasil atau pencetak uang dengan cara berlebihan.

Sebagai pekerja sekaligus ibu rumah tangga (tugas utama perempuan), tidak menutup kemungkinan bagi perempuan itu dieksploitasi. Para perempuan yang mempunyai beban ganda (double burden) terkadang tidak menyadari bahwa mereka sedang dieksploitasi. Fokus pikiran mereka terpecah karena beban yang mereka tanggung, sehingga ketika mereka menjalankan tugas sebagai pekerja, yang mereka pikirkan adalah mendapatkan uang sebanyak mungkin, meski dengan bayaran upah yang tidak sebanding dengan beban kerja yang mereka terima.

Semakin canggihnya sains dan teknologi, menjadikan kaum perempuan sebagai objek paling ampuh terutama dalam hal meraup keuntungan yang melimpah. Hal ini dikarenakan, sosok perempuan merupakan sosok yang identik dengan sosok yang cantik, anggun, lemah gemulai, sehingga dengan menggunakan perempuan untuk meraup keuntungan yang berlimpah sudah wajar dilakukan pada masa sekarang. Mereka menjadi objek eksploitasi sistem kapitalis yang memandang materi adalah segalanya. Para perempuan ini, sadar dan tidak, menjadi ujung tombak dalam sistem ekonomi kapitalis. Model, sales promotion girl, public relation hingga profesi sebagai pelobi hampir senantiasa berada di pundak kaum perempuan. Mereka menjadi umpan dan bahkan sekadar "gula-gula" dalam mendatangkan pundi-pundi rupiah (indoforum.org, Asri Supatmiati, 12/ Februari/ 2012).

Eksploitasi terhadap perempuan, khususnya di bidang ekonomi tidak jarang kita temui dalam kehidupan sehari-hari, baik di media cetak ataupun elektronik. Keduanya samasama menggunakan perempuan sebagai komoditi utama dalam hal meraup keuntungan yang melimpah. Penggunaan perempuan dalam kedua hal tersebut dikarenakan perempuan lebih mempunyai daya jual yang lebih tinggi daripada laki-laki. Kecantikan dan kemolekan tubuh yang mereka miliki, menjadi daya tarik tersendiri bagi para peminat kedua media tersebut di atas. Tak dapat dipungkiri, kecantikan fisik adalah sisi yang paling menarik dari seorang perempuan. Pada sistem materialistik sekarang, kecantikan fisik ini dilirik banyak kalangan pemodal dan dijadikan sebagai komoditas yang bisa mencetak uang. Fenomena ajang kontes kecantikan mulai dari sifatnya nasional sampai mendunia membuktikan akan hal tersebut. Perempuan dijadikan sebagai alat untuk mempromosikan produk, mulai dari pakaian, aksesoris, sampai sepatu. Yang lebih ironis adalah ketika perempuan ditampilkan sebagai mascot untuk produk makanan yang tidak ada kaitannya dengan keperempuanan. Jelas ini adalah salah satu bukti adanya eksploitasi besar-besaran terhadap perempuan di negeri kita ini (alpenprosa.wordpress.com, Amany Sholihah STP, 12/ Februari/ 2012). 


\section{1 -138 | HARKAT: Media Komunikasi Islam Tentang Gender dan Anak, 11 (2), 2015}

Di tengah himpitan ekonomi yang semakin menyesakkan dada, perkara eksploitasi perempuan dapat dikesampingkan demi segepok uang. Apalagi, secara individual, eksploitasi ini memang memberikan keuntungan materi bagi pelakunya. Konsep dangkal tentang citra dan jati diri perempuan yang selalu dikaitkan dengan keindahan fisik ini akan menjerumuskan kaum perempuan pada berbagai masalah yang dapat menimbulkan kekacauan, baik pada tataran individu maupun masyarakat (alpenprosa.wordpress.com, Amany Sholihah STP, 12/Februari/2012). Keindahan fisik yang dijadikan alasan sebagai pendatang keutungan bukan satu-satunya alasan kenapa perempuan yang dipilih dibandingkan laki-laki. Lebih itu dari, ternyata dari segi upah, perempuan cenderung lebih murah daripada laki-laki. Hal ini masih sangat dipengaruhi oleh budaya patriarkhi yang selalu beranggapan bahwa kedudukan perempuan berada dibawah laki-laki.

Budaya patriarkhi yang berkembang subur dimasyarakat semakin menguatkan kaum kapitalis dalam menjalankan tujuannya, dimana salah satunya adalah mendapatkan keuntungan melimpah tanpa mengeluarkan biaya besar. Dan hal ini dapat dilakukan dengan cara mempekerjakan perempuan.

Ada hal penting yang perlu kita ketahui, khususnya tentang simbol-simbol penggunaan perempuan dalam komoditi bisnis menurut perspektif feminis. Di dalam Feminist Legal Theory, terdapat empat aliran utama feminisme, masing-masing Feminisme Liberal, Feminisme Radikal, Feminisme Kultural, dan Feminisme Post-modern (Sulistyowati Irianto (ed.), 2008: 43).

Dari empat aliran tersebut, menurut penulis, yang paling cocok untuk membahas permasalahan mengenai simbol-simbol penggunaan perempuan dalam komoditi bisnis adalah aliran Feminisme Radikal. Hal ini dikarenakan, Feminisme Radikal memiliki konsep utama tentang perbedaan melalui tokohnya Chaterine MacKinnon lewat tulisannya Feminism Unmodified. Menurutnya, karena laki-laki mendefinisikan perempuan berbeda, perempuan tidak akan pernah dapat mencapai kesetaraan. Selain itu karena laki-laki mendominasi perempuan, permasalahan sebenarnya berkaitan dengan masalah kekuasaan (power). Pemuka aliran radikal tersebut mencoba mendefinisikan kembali pengertian 'women', dan mencari penjelasan dan pemahaman tentang dunia dari sudut pandang perempuan, karena mereka beranggapan selama ini dunia telah dibentuk oleh laki-laki. Pembentukan dunia oleh laki-laki ini dianggap 'phallocentric' dan penindasan, khususnya yang tercermin pada dukungan atau izin yang diberikan untuk terjadinya kekerasan terhadap perempuan (Sulistyowati Irianto (ed.), 2008: 44).

Apa yang telah dikemukakan oleh aliran Feminisme Radikal, tentunya tidak jauh berbeda dengan penggunaan perempuan sebagai simbolsimbol komoditi bisnis sebagaimana dikemukakan di atas. Karena para pebisnis mempunyai pikiran bahwa perempuan itu berbeda, artinya perempuan itu identik dengan sesuatu yang lembut, cantik, dan feminim, sehingga kemungkinan untuk mendapatkan keuntungan dengan menggunakan perempuan dalam komoditi bisnis sangatlah besar. Oleh karena ada pemikiran seperti itu, maka kemungkinan bagi perempuan untuk tidak menjadi simbol dalam komoditi bisnis sangatlah kecil, hal ini sesuai dengan apa yang telah dikemukakan oleh aliran Feminisme Radikal.

\section{PEMBAHASAN}

Eksploitasi Perempuan: Perspektif Islam dan Hukum Positif

Persoalan perempuan adalah sebuah realitas yang telah banyak melewati berbagai tantangan dalam sejarah kemanusiaan. Pada zaman jahiliyah primordial, perempuan 
dipandang hanya sebagai alat produksi keturunan yang secara sepenuhnya menjadi hak milik lakilaki. Pada masa itu, perempuan telah banyak merasakan berbagai derita, berbagai jenis keterbelakangan, dan juga berbagai jenis ketidakadilan seperti kefakiran, penyakit, buta huruf, serta eksploitasi (Sebuah Deskripsi Pengantar tentang: Peranan Perempuan dalam Sistem Pemerintahan Islam Iran Menimbang Realitas Hak Asasi Perempuan di Iran, Makalah disampaikan di Seminar Akhir Tahun 2011 Perempuan, Hak Asasi dan Dunia Islam, Konselor Budaya Kedubes Republik Islam Iran di Indonesia, Yogyakarta, 15 Desember 2011, hlm. 1). Wanita dimasa jahiliyah adalah sosok yang dipinggirkan dan tidak dihargai. Hal itu digambarkan dengan rasa malu yang melingkupi mereka ketika dikaruniai seorang anak wanita. Malu, penyesalan, dan kebencian, yang selanjutnya digambarkan oleh Allah lewat firman-Nya: (http: Iwww.minbarindo.com, 12/Februari /2012).

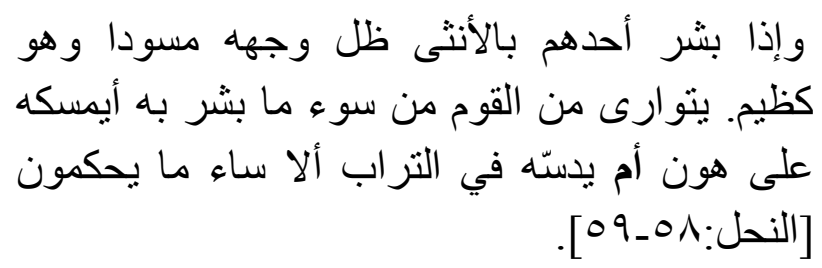

Artinya: "Dan apabila seseorang dari mereka diberi kabar dengan (kelahiran) anak perempuan, hitamlah (merah padamlah) mukanya, dan ia sangat marah. Ia menyembunyikan dirinya dari orang banyak, disebabkan buruknya berita yang disampaikan kepadanya (hingga ia pun berfikir) haruskah dia memeliharanya dengan menanggung kehinaan ataukah akan menguburkannya ke dalam tanah (hidup-hidup)? Ketahuilah, alangkah buruknya apa yang mereka tetapkan itu." (An-Nahl: 5859).

Secara obyektif, wanita di waktu itu hidup dalam masa yang serba rumit, terutama dilingkungan masyarakat Arab. Mereka tidak menghendaki kelahiran wanita. Di antara mereka ada yang mengubur wanita hidup-hidup hingga mati dikalang tanah (Shalih bin Fauzan bin Abdullah Al-Fauzan, 2005: 15-16). Tidak semua anak perempuan yang dilahirkan, dikubur hidup-hidup, akan tetapi ketika ada diantara mereka yang membiarkan anak-anak wanita itu hidup hingga dewasa, mereka dihinakan, dieksploitasi dan dijadikan sebagai harta yang diwariskan setelah suaminya meninggal (http: Iwww.minbarindo.com, 12/Februari 12012). Hal ini sebagaimana firman Allah dalam QS.An-Nisaa':19:

كانو إذا مات الرجل كان أولياؤه أحق بإمر أتنه، إن

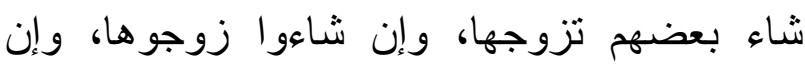

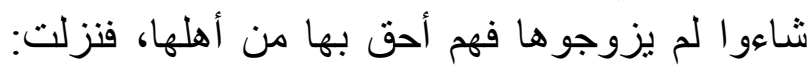

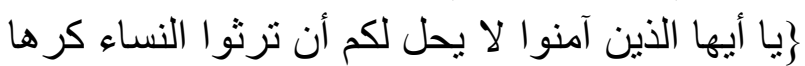

[النساء: 9 19.

Artinya: "Dahulu jika seorang suami meninggal maka keluarga sang suami adalah yang paling berhak atas sang istri daripada keluarga sang wanita itu sendiri. Apabila diantara mereka ingin menikahinya, maka ia akan melakukannya. Dan bila mereka ingin menikahkannya, maka mereka pun berkuasa untuk melakukannya. Demikian hal itu terus berlangsung hingga Allah berfirman, 'Hai orang-orang yang beriman, tidak halal bagi kamu mempusakai wanita dengan jalan paksa." (An-Nisa':19)

Penderitaan wanita rupanya tidak berhenti disitu saja, hal ini dikarenakan masih banyak perlakuan-perlakuan yang tidak sepatutnya diterima oleh kaum perempuan tersebut, seperti halnya dalam permasalahan perkawinan. Di masa jahiliyyah, orang-orang menikahi wanita dengan jumlah yang tidak terbatas, dan memperlakukan mereka secara tidak manusiawi. Selain itu, wanita-wanita yang ditinggal wafat oleh suaminya tetap berstatus sebagai istri, dan tidak boleh keluar dari rumahnya selama setahun. Di sisi lain, seorang laki-laki di masa jahiliyyah, bebas mentalak (mencerai) dan rujuk kembali dengan istrinya sebelum tiba batas 'iddah-nya. 


\section{3-138 | HARKAT: Media Komunikasi Islam Tentang Gender dan Anak, 11 (2), 2015}

Hingga datanglah Islam yang membatasi talak raj'i (talak yang masih memungkinkan bagi suami untuk rujuk) hingga dua kali talak (http: Iwww.minbarindo.com, /2012).

Kedudukan perempuan sesudah Islam datang, jelas berbeda dengan sebelum Islam datang. Hal ini dikarenakan Islam benar-benar mengangkat dan memuliakan perempuan. Perempuan diberikan hak-haknya, disamakan kedudukannya dengan laki-laki. Dan hanyalah Allah melebihkan kaum lelaki atas kaum wanita pada beberapa keadaan karena sebab dan hikmah tertentu, seperti dalam masalah waris, saksi, kepemimpinan, talak dan beberapa masalah lainnya. Allah berfirman: (http: Iwww.minbarindo.com, 12/Februari /2012).

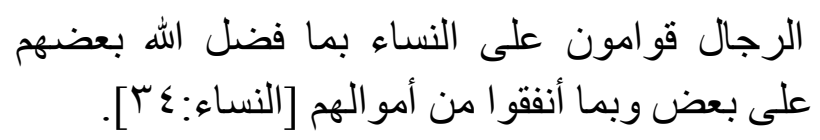

Artinya:"Kaum laki-laki itu adalah pemimpin bagi kaum perempuan, oleh karena Allah telah melebihkan sebahagian mereka (lakilaki) atas sebahagian yang lain (wanita), dan karena mereka (laki-laki) telah menafkahkan sebagian dari harta mereka." (An-Nisaa': 34)

Di dalam Islam, antara laki-laki dan perempuan kedudukannya sama. Hal ini dibuktikan dengan apa yang telah disebutkan didalam Al-Qur'an. Dalam al-Quran, sebutan perempuan (an-nisa) dipergunakan sebanyak 57 kali, sama dengan kata rajul atau rijal atau aluntsa yang berpasangan dengan adz-dzakar yang disebut sepuluh kali. (Said Aqil Siroj, 2006: 244) Perimbangan penyebutan ini selintas mengindikasikan bahwa antara kedua jenis kelamin tersebut, sungguhpun memiliki perbedaan, tetap diperlakukan dan diperhatikan secara berimbang dan adil oleh Islam (Said Aqil Siroj, 2006: 244). Oleh karena itu, dalam wilayah seperti itu dimana ciri jenis kelamin tidak ada hubungnnya dengan status dan fungsi seseorang, pria dan wanita dapat menikmati status yang sama dan melakukan fungsi yang sama (Sidney Hook,dkk., 1987: 227).

Sudah banyak bukti-bukti yang menyatakan betapa mulia dan tingginya kedudukan dan derajat perempuan didalam Islam. Hal ini diantaranya dapat dibuktikan dengan sabda Nabi Muhammad Saw ketika ditanya oleh seorang sahabat, "Siapa diantara Manusia yang paling utama untuk dihormati?" Beliau menjawab, "ibumu." "Kemudian siapa lagi?" tanya sahabat lagi. "Ibumu." Lanjut Nabi lagi. "Siapa lagi?" tanya sahabat ketiga kalinya. "Ibumu," lanjut Nabi lagi. "Siapa lagi?" tanyanya lagi. Nabi pun kemudian menjawab, "Ayahmu." (HR Bukhari dan Muslim). Selain itu, dalam hadis lain, Nabi juga bersabda, "Al-Jannatu tahta aqdami-l-ummahati" (Surga itu ada dibawah telapak kaki ibu) (Sidney Hook,dkk., 1987: 244). Bukti-bukti lain bahwa wanita di dalam Islam mendapatkan perlidungan dan kedudukan yang sama dengan laki-laki adalah perempuan diberi hak waris, hak milik merekapun diakui. Selain itu, pada saat Nabi Muhammad Saw melakukan haji wada', Nabi secara khusus berwasiat agar senantiasa menjaga wanita.

Dengan mengetahui kedudukan perempuan baik sebelum dan sesudah Islam datang, dapat disimpulkan bahwa ekploitasi terhadap perempuan, khususnya di bidang ekonomi jelas bertentangan dengan misi Islam. Islam menempatkan perempuan dalam kedudukan yang tinggi dan mulia. Sejak Islam datang, perempuan tidak lagi diperlakukan secara sewenang-wenang dan tidak dihormati sebagaimana yang terjadi pada zaman jahiliyah. Kedatangan agama Islam, benar-benar membuat kedudukan kaum perempuan naik derajatnya dan dimuliakan. Sejak Islam datang, perempuan benar-benar mendapatkan kedudukannya sesuai kodratnya.

Di dalam Islam, antara laki-laki dan perempuan sama-sama mempunyai kewajiban 
untuk menjaga kehormatannya, sebagai suatu tindakan pencegahan, hukum Islam melarang orang Islam terlibat dalam setiap praktik sosial yang dapat mengarah pada suatu perwujudan asusila. Karena itu al-Qur'an memerintahkan agar supaya pria dan perempuan memelihara kehormatannya dan menyucikan tingkah lakunya (QS. Al-Ahzab (33:35).

Untuk menyeimbangkan pembatasanpembatasan tambahan terhadap perempuan, Islam menyediakan langkah-langkah khusus untuk melindungi reputasi mereka dari tuduhan tak bermoral yang tidak benar (QS. An-Nuur (24:4). Islam menekankan masalah kehormatan bagi perempuan, dan oleh karena itu terdapat peraturan-peraturan tentang penampilan mereka dan tingkah laku dalam masyarakat daripada peraturan serupa yang memerintahkan golongan pria. Memang al-Qur'an menetapkan bahwa perempuan harus selalu berpakaian dan berkelakuan sedemikian rupa, sehingga tidak menimbulkan gairah lelaki atau menimbulkan kecurigaan terhadap moralitasnya sendiri (Sidney Hook,dkk, 1987:253).

Adanya penekanan dan pembatasan tersebut, tujuannya adalah untuk melindungi kaum perempuan itu sendiri, agar para kaum perempuan tersebut terlindungi dari hal-hal yang dapat membahayakan kehormatan mereka. Selain perlindungan-pelindungan di atas, ada pula perlindungan lainnya yaitu sebagaimana pesan Nabi Muhammad Saw pada saat melakukan haji wada', Nabi secara khusus berwasiat agar senantiasa menjaga perempuan.

Jika kembali menelaah keterlibatan perempuan dalam pekerjaan pada masa awal Islam, maka tidaklah berlebihan jika dikatakan bahwa Islam membenarkan mereka aktif dalam berbagai aktivitas. Para perempuan boleh bekerja dalam berbagai bidang, di dalam ataupun di luar rumahnya, baik secara mandiri atau bersama orang lain, dengan lembaga pemerintah maupun swasta, selama pekerjaan tersebut dilakukannya dalam suasana terhormat, sopan, serta selama mereka dapat memelihara agamanya, serta dapat pula menghindari dampak-dampak negatif dari pekerjaan tersebut terhadap diri dan lingkungannya (M. Quraish Shihab, 1996: 429).

Dengan ilmu pengetahuan dan keterampilan yang dimiliki oleh setiap orang, termasuk kaum wanita, mereka mempunyai hak untuk bekerja dan menduduki jabatan jabatan tertinggi. Hanya ada jabatan yang oleh sementara ulama dianggap tidak dapat diduduki oleh kaum wanita, yaitu jabatan Kepala Negara (Al-Imamah Al-'Uzhma) dan Hakim. Namun, perkembangan masyarakat dari saat ke saat mengurangi pendukung larangan tersebut, khususnya menyangkut persoalan kedudukan perempuan sebagai hakim ((M. Quraish Shihab, 1996: 431). Hal ini dapat dibuktikan dengan adanya seorang wanita yang menjadi hakim, yang selama ini masih ada yang menganggap bahwa kedudukan perempuan sebagai hakim tidaklah tepat karena berbagai macam alasan.

Di dalam hal kaitannya dengan penghasilan yang diperoleh istri, seorang laki-laki (suami) tidak punya hak apa pun untuk mendapatkan manfaat ekonomi dari perempuan (istri). Hal ini dikarenakan di dalam Islam kewajiban mecari nafkah ada pada laki-laki dalam kapasitasnya sebagai seorang suami. Lakilaki dalam kapasitasnya sebagai seorang suami berkewajiban memberikan nafkah baik lahir maupun batin kepada istrinya (Murtadha Muthahhari, 2011: 47). Walaupun pembelanjaan untuk istri merupakan bagian dari pembelanjaan keluarga dan merupakan tanggung jawab si suami, namun dalam pandangan Islam, suami tidak berhak mengambil keuntungan finansial dari istri ataupun meminta bagian dari penghasilan si istri, suami tidak bisa mengeksploitasinya (Murtadha Muthahhari, 1995: 145). Karena sesungguhnya perempuan tidaklah berkewajiban mencari nafkah bagi keluarganya. Perempuan boleh bekerja hanya 


\section{5-138 | HARKAT: Media Komunikasi Islam Tentang Gender dan Anak, 11 (2), 2015}

sebagai wujud dari apresiasi diri mereka bukan sebagai tulang punggung keluarga.

Tidak jauh berbeda dengan apa yang telah diatur di dalam hukum Islam, dalam konteks hukum positif, eksploitasi ekonomi terhadap perempuan tidak dapat dibenarkan, karena hal ini bertentangan dengan hak asasinya sebagai perempuan. Beberapa regulasi hukum tersebut, diantaranya adalah:

1. Undang-Undang Nomor 39 Tahun 1999 tentang Hak Asasi Manusia;

Di dalam Undang-Undang Nomor 39 Tahun 1999 tentang Hak Asasi Manusia, perempuan yang digolongkan dalam kelompok masyarakat rentan (vulnerable people) mendapat tempat khusus dalam pengaturan jaminan perlindungan hak asasi manusia (Rhona K. M. Smith dkk,. 2008:269). Di dalam undangundang tersebut, hak perempuan termasuk bagian kesembilan dan diatur dalam Pasal 45 sampai Pasal 51. Selain itu, dalam undangundang tersebut juga diatur mengenai hak atas kesejahteraan, dimana hak-hak tersebut meliputi hak milik, hak atas pekerjaan, hak mendirikan serikat pekerja, hak atas kehidupan yang layak, hak atas jaminan sosial dan hak atas perawatan.

Pengakuan terhadap hak-hak tersebut diatas ditujukan bagi semua orang baik laki-laki maupun perempuan. Hal ini, dapat disimpulkan bahwa baik laki-laki maupun perempuan mempunyai hak yang sama terutama dalam hal ini kaitannya dengan hak milik dan hak atas pekerjaan. Jadi berdasarkan pengakuan tersebut, dapat disimpulkan bahwasanya segala macam hal yang dapat timbul atau terjadi akibat dilanggarnya hak tersebut, seperti eksploitasi ekonomi perempuan tidak dapat dibenarkan.

2. The Convension on the Elimination of All Forms of Discrimination Againts Women (CEDAW) yang sudah diratifikasi melalui melalui Undang-Undang Nomor 7 Tahun 1984;
Sebagai kelompok rentan, perempuan memiliki posisi khusus yang berbeda dari lakilaki. Pemberian posisi khusus ini bertujuan untuk memberikan perlindungan bagi kaum perempuan itu sendiri agar ia dapat terhindar dari segala macam hal yang dapat membuatnya tidak dapat menikmati kebebasan asasinya secara utuh. Salah satu hal yang dapat membuat perempuan tidak dapat menikmati kebebasan asasinya secara utuh adalah eksploitasi ekonomi yang seringkali tidak disadari oleh perempuan.

Berdasarkan konvensi tersebut perempuan perempuan juga punya hak yang sama dengan laki-laki untuk memilih pekerjaan atau profesi dan hak yang sama pula bagi kedua pasangan dalam menghormati kepemilikan, perolehan, pengelolaan, manajemen, pengelolaan, penikmatan, serta pemindah-tanganan kekayaan baik secara cuma-cuma maupun berdasarkan pertimbangan nilainya. Adanya ketentuan tersebut, sebenarnya ingin memberikan penekanan bahwasanya perempuan tidak boleh dieksploitasi khususnya secara ekonomi. Akibat yang timbul dari persamaan tersebut berimbas pada hal-hal lainnya, seperti akses untuk memperoleh pekerjaan, pemberian upah, jam kerja dan sebagainya.

\section{Konvensi-Konvensi Dasar International Labour organization;}

Organisasi Perburuhan Internasional merupakan penganjur awal hak perempuan. Organisasi Perburuhan Internasional ini mengakui bahwa perempuan membutuhkan perlindungan terutama dalam situasi pekerjaan yang rentan dan dalam lingkungan yang berbahaya. Kepedulian Organisasi Perburuhan Internasional adalah memastikan kesetaraan upah dan kondisi kerja bagi laki-laki dan perempuan. Saat ini standarnya ditetapkan dalam Konvensi No. 111 mengenai Diskriminasi dalam Pekerjaan dan jabatan, 1985, dan Konvensi No. 100 mengenai Renumerasi Setara antara LakiLaki dan Perempuan. Intinya instrumen- 
instrumen ini menetapkan bahwa laki-laki dan perempuan harus diperlakukan setara dalam hal akses ke pekerjaan, persyaratan dan kondisi kerja, pemecatan dan renumerisasi (Rhona K. M. Smith,dkk., 2008: 163). Selain itu dapat disimpulkan bahwa adanya penekanan kesamaan hak khususnya kesamaan upah tersebut merupakan bentuk perlindungan bagi setiap orang khususnya perempuan yang selama ini selalu diidentikkan sebagai golongan kelas 2 (subordinasi).

Selain beberapa regulasi hukum yang disebutkan diatas, ada beberapa regulasi hukum lainnya yang berkaitan dengan hak asasi perempuan khususnya yang berkaitan dengan perlindungan perempuan dari eksploitasi, regulasi-regulasi tersebut diantaranya adalah Kovenan Internasional tentang Hak Ekonomi, Sosial dan Budaya yang sudah diratifikasi melalui melalui Undang-Undang Undang-Undang Nomor 11 Tahun 2005; Undang- Undang Nomor 13 Tahun 2013 tentang Ketenagakerjaan; Undang-Undang Nomor 8 Tahun 1981 tentang Perlindungan Upah; Peraturan Menteri Tenaga Nomor 8.per04/Men/1989 tentang Syarat-Syarat Kerja Malam dan Tata Cara Mempekerjakan Perempuan pada Malam Hari; Keputusan Menteri Tenaga Kerja dan Transmigrasi Republik Indonesia Nomor Kep.224/Men/2003 tentang Kewajiban Pengusaha yang Mempekerjakan Pekerja atau Buruh antara pukul 23.00 sampai pukul 07.00.

Secara garis besar, beberapa regulasi hukum sebagaimana disebutkan diatas mempunyai tujuan yang sama yaitu dalam rangka memberikan perlindungan hukum terhadap perempuan khususnya dari eksploitasi ekonomi. Semua regulasi hukum tersebut, bilamana dikaitkan dengan hak asasi perempuan dalam hal kepemilikan dan hak atas pekerjaan, memberikan kesempatan yang sama antara lakilaki dan perempuan. Jadi perempuan juga mempunyai kesempatan yang sama atas harta benda yang ia miliki dan ia juga mempunyai kebebasan untuk menikmati segala hal yang menjadi miliknya tanpa adanya intervensi dari pihak manapun, serta ia juga mempunyai kesempatan yang sama untuk memperoleh pekerjaan yang layak dan upah yang layak sebagaimana yang diperoleh laki-laki.

Persamaan hak tersebut bertujuan agar perempuan yang digolongkan sebagai kelompok rentan dapat memperoleh perlindungan hukum khususnya dari eksploitasi ekonomi. Jadi segala macam bentuk eksploitasi ekonomi perempuan tidak dapat dibenarkan. Apapun profesi atau pekerjaan yang dipilih oleh perempuan misal model, sales promotion girl, public relation hingga pelobi tetap harus dilindungi dan tidak boleh dieksploitasi. Artinya, tenaga dan pikiran yang dikeluarkan oleh mereka harus dihargai selayaknya manusia seutuhnya. Faktor keindahan fisik jangan dijadikan ajang untuk memperoleh keuntungan yang besar.

Perlindungan lain yang juga diberikan kepada perempuan adalah kesempatan yang sama untuk memilih pekerjaan atau profesi dan hak yang sama pula bagi kedua pasangan dalam menghormati kepemilikan, perolehan, pengelolaan, manajemen, pengelolaan, penikmatan, serta pemindah-tanganan kekayaan baik secara cuma-cuma maupun berdasarkan pertimbangan nilainya. Adanya ketentuan tersebut, menunjukkan bahwa perempuan tidak boleh dieksploitasi khususnya secara ekonomi, karena selain mempunyai hak yang sama untuk memilih pekerjaan, perempuan juga punya hak yang sama dalam perolehan dan pengelolaan kekayaannya.

Terlepas dari permasalahan beban ganda maupun eksploitasi ekonomi yang dialami oleh perempuan, niat pemerintah untuk mengembangkan pembangunan ekonomi yang berwawasan gender patut diapresiasi dengan baik. Hal ini dikarenakan niat dan konsep awal 


\section{7-138 | HARKAT: Media Komunikasi Islam Tentang Gender dan Anak, 11 (2), 2015}

dari dicanangkannya pembangunan ekonomi yang berwawasan gender adalah demi kesejahteraan kaum perempuan.

\section{PENUTUP}

Kesejahteraan yang diharapkan mampu memperbaiki dan meningkatkan taraf kehidupan para perempuan khususnya perempuanperempuan yang minim pengetahuan dan keterampilan. Meskipun dalam kenyataannya, apa yang diharapkan masih jauh dari harapan pemerintah maupun masyarakat. Salah satu penyebab tidak terpenuhinya harapan tersebut, adalah masih adanya oknum-oknum yang memanfaatkan kondisi dari perempuan yang kemudian menjadikan perempuan tersebut dieksploitasi. Selain itu lemahnya, perlindungan hukum bagi perempuan yang dieksploitasi juga menjadi penyebab dari tidak tercapainya tujuan pembangunan ekonomi yang berwawasan gender.

Beberapa langkah yang dapat ditempuh oleh pemerintah, menurut penulis di antaranya adalah:

1. Mengembangkan dan menyempurnakan berbagai perangkat hukum yang sudah ada agar perlindungan terhadap perempuan bisa dioptimalkan lagi;

2. Memberikan jaminan dan kepastian hukum bagi perempuan terutama dalam memperoleh keadilan;

3. Memberikan sanksi tegas bagi semua pihak yang melakukan eksploitasi terhadap perempuan, khusunya kaum pemodal yang dengan sengaja memanfaatkan kaum perempuan demi meraup keuntungan yang melimpah tanpa diimbangi pemberian upah yang layak.

4. Meningkatkan kualitas hidup perempuan dalam segala bidang terutama di bidang kesehatan dan pendidikan;
5. Menyediakan sarana dan prasana yang diperlukan dalam rangka meningkatkan kualitas hidup perempuan;

6. Memberikan penyuluhan-penyuluhan hukum terhadap perempuan agar mereka menyadari bahwa hak-hak asasi mereka dilindungi oleh hukum. Sehingga dengan begitu, apabila terjadi pelanggaran atau indikasi-indikasi eksploitasi, mereka dapat dengan segera melaporkan ke pihak yang berwenang;

\section{DAFTAR PUSTAKA}

Keputusan Menteri Tenaga Kerja dan Transmigrasi Republik Indonesia Nomor Kep.224/Men/2003 tentang Kewajiban Pengusaha yang Mempekerjakan Pekerja atau Buruh antara pukul 23.00 sampai pukul 07.00.

Konvensi No. 100 mengenai Renumerasi Setara antara Laki-Laki dan Perempuan.

Konvensi No. 111 mengenai Diskriminasi dalam Pekerjaan dan jabatan, 1985.

M. Quraish Shihab. 1996. Membumikan AlQuran Fungsi dan Peran Wahyu dalam Kehidupan Masyarakat. Mizan, Bandung.

Mansour Fakih. 1996. Analisis Gender dan Transformasi Sosial, Pustaka Pelajar, Yogyakarta.

Murtadha Muthahhari. 1995. Hak-Hak Wanita dalam Islam. Lentera, Jakarta.

Falsafah Hijab Teologi Sosial Hijab Perempuan dalam Konsep Islam. Ctk. KeII, RausyanFikr, Yogyakarta.

Peraturan Menteri Tenaga Nomor 8.per04/Men/1989 tentang Syarat-Syarat Kerja Malam dan Tata Cara Mempekerjakan Perempuan pada Malam Hari. 
Rhona K. M. Smith,dkk. 2008. Hukum Hak Asasi Manusia, ctk. Pertama, Pusat Studi Hak Asasi Manusia Universitas Islam Indonesia (PUSHAM UII), Yogyakarta.

Said Aqil Siroj. 2006. Tasawuf sebagai Kritik Sosial. Mizan, Bandung.

Sebuah Deskripsi Pengantar tentang: Peranan Perempuan dalam Sistem Pemerintahan Islam Iran Menimbang Realitas Hak Asasi Perempuan di Iran, Makalah disampaikan di Seminar Akhir Tahun 2011 Perempuan, Hak Asasi dan Dunia Islam, Konselor Budaya Kedubes Republik Islam Iran di Indonesia, Yogyakarta, 15 Desember 2011.

Sidney Hook,dkk. 1987. Hak Azazi Manusia dalam Islam, Yayasan Obor Indonesia, Jakarta.

Siti Musdah Mulia. 2011. Muslimah Sejati, Marja.
Sulistyowati Irianto (ed.). 2008. Perempuan dan Hukum: Menuju Hukum yang berspektif Kesetaraan dan Keadilan. Yayasan Obor Indonesia (YOI), Jakarta.

Undang-Undang Nomor 13 Tahun 2013 tentang Ketenagakerjaan, Undang-Undang Nomor 8 Tahun 1981 tentang Perlindungan Upah.

Undang-Undang Nomor 39 Tahun 1999 tentang Hak Asasi Manusia.

Undang-Undang Nomor 7 Tahun 1984 tentang Pengasahan The Convension on the Elimination of All Forms of Discrimination Againts Women (CEDAW).

Undang-Undang Undang-Undang Nomor 11 Tahun 2005 tentang Ratifikasi atas Kovenan Internasional tentang Hak Ekonomi, Sosial dan Budaya. 